Copyright (C) 2019 by Academic Publishing House Researcher

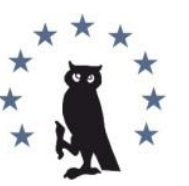

Published in the Russian Federation

European Researcher. Series A

Has been issued since 2010.

E-ISSN 2224-0136

2019, 10(1): 50-58

DOI: 10.13187/er.2019.1.50

www.erjournal.ru

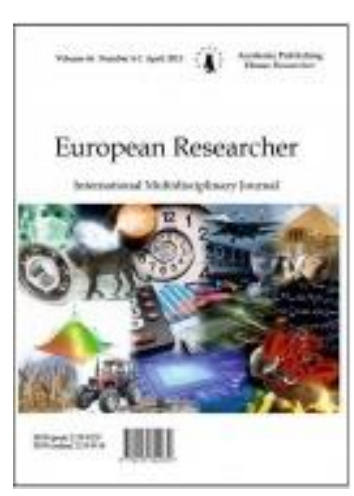

\title{
The Impact of Ethno-Politics in Iraq
}

\author{
Shno Muhammed Khalnd a, Filiz Katman a, * \\ a Istanbul Aydin University, Turkey
}

\begin{abstract}
This paper is focused on an overview of the main impact of ethno-politics in Iraq, recalling the fact that politics was rebuilt with respect to religious and ethnic lines and political alliances were reshaped over these set lines. Withdrawal of American troops and internal differences of Iraqi parties triggered political balances, which are not limited into just sectarian and ethnic bases. The political and strategic effort of Arab Spring and internal power struggle among Iraqi political groups entered into a new phase in politics. The rising challenges of ethno-politically inspired conflicts in IR discipline are neither new nor unexpected. Different scholars of ethno-political studies in IR discipline have suggested different approaches to addressing ethnic inspired conflicts, which sometimes arises as a result of quest for self-determination especially when there is a growing consciousness of nationhood. These approaches include confederation, federation and political autonomy. However, most of these theories have failed to explain whether the aspiring ethno nation's involved feels accommodated with the institutional arrangements of each approach.

Keywords: Iraq, ethno-politics, federalism, democracy.

\section{Introduction}

Developing interest in researching about ethnic politics in international relations especially in ethnically polarized Iraq is a process in showing the degree of differences that exist between the various entities in political bargaining. Iraq dissects as a state, through the fronts of regionalism and its effect on a national government. Many Iraqis may have come to agree with the ethnic politics in Iraq, and the way its negative consequences influences the political opinion of the country, which practically is divided into regional construct.

This paper also provides insight into the conditions surrounding ethno-politics in international relations and how it shapes states' behavior especially in ethnically polarized Iraq and its lopsided political system. It lay more stress on the state of Iraq; the politics of Iraq before, during and after the era of Saddam Hussein; a look on the transition process and political reconciliation. Finally, it outlines the security challenges and responses, elaborates on the ethnopolitics and political structure in Iraq with more focus on the ethnic and religious structure of Iraq, political structure, and Kurds in the midst of US policy after Saddam Hussein.
\end{abstract}

\footnotetext{
* Corresponding author

E-mail addresses: filizkatman@aydin.edu.tr (F. Katman), shna_hewliri@yahoo.com (S.M. Khalnd)
} 


\section{Discussion \\ Ethno-Political Theory}

The theoretical background through, which ethno-political theories in International Relations discipline IR was built, was constructed from varieties of theoretical frameworks offered in other sister disciplines such as sociology, anthropology and as well as classical philosophical studies. Thus, ethno-political studies selected these frameworks in general terms and alongside two focal questions: What is the nature of ethnicity and ethnic consciousness? Are there any possibilities of multiethnic society? Hence, the analyses of multiethnic societies are distinguished in line with incompatibility. Scholars in these sense of reasoning includes John Stuart Mill, Woodrow Wilson, and consociationalism, which is characterized by plural society theory proposed by J. S. Furnivall and Anthony Smith. In a similar perspective, both Mill (Mill, 2009: 344) and (Ryan, 1990: 4-5), argued that "there is no possibility for free institutions in a country that is made up of different ethnic nationalities. Within a society without a common fraternity, especially if they read and speak different languages, the united public opinion necessary to the working of representative government cannot exist." Contrary to this argument, it is claimed that human beings in the multi ethnic society can peaceful coexist except in the market place, which he argues that it will be necessary to impose laws.

Notably, the breakthrough of the theories of ethno-politics started from the study of ethnic conflicts, which emerged between 1960's and then 1990's hence ascribing the study of ethnopolitics to be dominated with ethnic conflicts. The dominance is associated with the conventional inference that ethnicity is by definition conflictual and studies of ethno-politics is the study of conflicts, in which ethnic groups is involved. However ethnic conflicts are considered as the most evidently and relevant issue in the studies of ethno-politics, but it has turned out that the studies of ethno-politics are not limited only to conflicts, and even not necessarily conflictual by its nature. In the light of this, Hale (Hale, 2008: 18) directly argues that "next to almost every ethnic hotspot lies multiple zones of ethnic peace". Put away the reductionist view of conceiving ethno-political studies through the lens of conflict, the studies of ethno politics has stood out as an enduring phenomenon of the post-Cold War international politics. Therefore, describing the studies of ethno-politics as the studies of ethnic conflict is completely uncalled for and does not necessarily define the phenomenon.

Hale (2008), in his book, started his theory by problematizing the inadequacies found among the current theories of ethno-political studies and offered what he considered as an alternative rational for theoretical basis. He therefore argues that theories of ethno-political studies are divided in two broad categories, namely "ethnicity-as-conflictual theories" and "ethnicity-asepiphenomenal theories". He further discredited both theories on the reason that ethno-political theories must have more solid and firmer basis Hale (Hale, 2008: 31). Hale's new approach was based on his relational and micro foundational theory, which its emphasis is rooted in psychology of human behavior. Meanwhile, his view comprises of two main arguments; ethno-politics and the nature of ethnicity. On the foundational theories of ethno-politics, which are primordialism and constructivism, Hale argued that they are not relational, since ethnicity is best described as instrument, through which human beings simplify, categorize and understand the complex world. Thus, equating ethnicity as an instrument of uncertainty reduction, therefore in his view ethnicity is not natural but a human creation, which he uses to understand the uncertainty of reality. His argument is closely related with Barth's description of ethnicity, which he explains as:

"Ethnic groups are categories of ascription and identification by the actors themselves, and thus have the characteristic of organizing interaction between people. We attempt to relate other characteristics of ethnic groups to this primary feature" (Barth, 1969: 10).

Hale's second argument was based on the premise that what one considers as ethno-politics is mainly a way through which human beings in the society seek to realize their self-interest. Thus, his conceptualization of ethno-politics involves the process of realizing human intrinsic behavior or individuals' desire in pursuing various interests Hale (Hale, 2008: 55). Human interest within this scope involves both material and emotional factors; therefore, it corresponds with the argument of Moynihan (Moynihan, 1993: 56) that the importance of ethnicity is because it combines effective ties with interest. So far, Hale's argument stands out as a solid framework for ethno-political theories; however, it still lacks a general conceptualization on how the theory should be analyzed. 
Realist theories of IR, particularly Structural Realism and Classical Realism analyzed states as unitary actors in the international political system, hence, the nature of politics are indifferent to the domestic environments and by definition to ethno politics (Lobell, Mauceri, 2004: 1). Ethnopolitics is seen as a "change in unit level"; thereby, it would not matter for the international system (Waltz, 2000: 5). Consequently, it can be argued that the neglect of ethno-political studies in IR theory is primarily caused by the dominance of Realism, given that the Realist tradition has dominated IR theory and together with Liberal theories has constituted "mainstream IR".

\section{Federalism}

According to Burgess and Gagnon (Burgess and Gagnon, 1993: 15), they regard federalism "as a political device for establishing viable institutions and flexible relationships capable of facilitating inner-state relation and inter-community co-operation". They further stated that it is "an expression of practices which encourages autonomy within regions" (Burgess and Gagnon, 1993: 16). Unlike other political phenomenon, federalism has so far gained a consensus agreement among scholars by consenting federalism as a political system having about two levels of government. Responsibilities of the government, jurisdiction and powers are drawn, ingrained and divided within the constitution. However, power depends on how it is distributed within the federated political system and what degree of autonomy should be granted to the regional/states. Lalande (1978) proposes four approaches to understanding federalism as a political system and they are as follows: (1) Constitutional or Institutional (2) Functional or Sociological (3) Federalism as a Process of Developmental (4) Federalism as a bargain or Political.

Institutional or constitutional approach: This method deals with government operating system of governance. It focuses on the institutional correspondence of a country; power devolution between regional/state level and Central Government. It is also focused on the constitutional provision that makes the two and three tiers of the state politically independent as recommended by the law.

Sociological or functional approach: this approach focuses on the social cohesion of a country and the level of ethnic diversities that inhabits it (Lalande, 1978). Federalism in this context is seen as an appropriate political system for handling ethnically polarized country with the freedom of self-expression and political autonomy of its constituent's parts. In same sense, Stein (1971) argued that, the concept of federation is not only focused on the formal division of power between substate (provinces, regions or cantons) and centers, but equally a social phenomenon as well. Federal society has a chance "where a society is constituted of territorially based communities which are clearly differentiated by language and ethnicity" (Stein, 1971: 34). Hence, there is a strong tendency for a federal society to be organized in respect to societal differences such as ethnicity, even if there are territorially inclined. Additionally, federalism can be organized in form of ethnic relations so as to maintain, preserve and promote viable and accommodated identities that can be coexisted in a peaceful and neighborly association.

Federalism as a developmental approach: According to Lalande (1978), this approach critically outlines the transactions and communication that exist between two/three tiers of government in other to solve issues. Here, the problems are well understood so long as there is tension produced by the diversity of the society. Therefore, federalism is considered to be "much more than a system of government. It is also a process of: ongoing negotiations, an art of resolving conflicts, an approach based on compromise and cooperation" (Auclair, 2005: 5). Within the corridors of federal structured state, solutions to problems are negotiated among constituent's parts other than a direct imposition by the central authority.

Federalism as a bargain approach: Lalande (1978), argues that this method focuses mainly on legalistic and political approach, so as to have a clue on federalism. Unlike institutional approach, federalism concentrates on the division of power between two tiers of government. Each of the levels of government safeguards the autonomy within its jurisdiction. The end product of political bargain however takes place during the manifestation in the division of powers, which is often considered to be in written constitution.

\section{Constitutionalism}

Constitutionalism as its name implies is often viewed as a synonym for a limited government and it seeks to prevent any arbitrary government. Arbitrary in this sense consist the abilities of rulers who govern with their free will, so as to serve their own interest and not the interest of the ruled. In order to avoid the dangers of this type of governance, there are mechanisms designed by 
constitutionalism to determine the person who can rule, how he can rule and for what purposes he can rule. There are two traditions, which are often within majority of democracies and most likely to be in line with most constitutions. The very first tradition is focused more on the design and functioning of democratic processes, with electoral system selection and choices that operates between the parliamentary and presidential forms of government and of federal or unitary arrangements. Looking at the case of Iraq, Shakir (Shakir, 2014: 163) argues that the Iraqi Constitution reflects the will of most Iraqis to build a government that is fully based on the rule of democracy and law. Backer (Backer, 2009: 676) denotes that there is no Iraq's history of constitutionalism that can serve as a means of evaluating substances, forms, and the legitimacy of the state's constitution. However, this implies that constitutions must be used to show the main principles and values that are of constitutionalism standards, which can be easy to assess the legitimacy of a government.

In Iraq, things that contribute in building a constitutional culture are the emphasis on the rule of law, power-sharing, the effective representation of the Iraq people within the government, and protection of freedom and human rights. Irrespective of the numerous number of instability within the country, new political rules have been established through the constitution so as to avoid any illegitimate activity. An example of this is the case of Sunni, where its position within the constitution and political process was shifted from the state of rejection and refusal of federal state legitimacy to a general acceptance and participation. Shakir (Shakir, 2014: 164), expresses that people have come to realization that the constitutional context and political process are mere games in town, used to obtain benefits and achieve goals. Another constitutionalism example is the campaign against the Iraqi Minister for Women's Affairs, which was initially initiated by December 2011, by some Iraqis as a result of the Minister's decision of issuing regulations which were not in liberal context of the constitution.

It is theoretically believed that Iraq is a Federal Democratic country. This believes is not true practically, because federalization and democratization are still in the process with the help to amend the constitution (Shakir, 2014: 164). In order to put an end to the state of instability and political crisis that happens in Iraq, there is a need to introduce more economic and political structures.

\section{Iraqi Politics before Saddam Hussein}

So far, there has not been a generally acceptable literature or documentary on the exact political history of Iraq before its formal definition as a modern state in 1920. However, the predominant political history of Iraq became more popular from the outbreak of the military coup that was led by General Abd al-karim Qasim, on July 14 1958, which overthrow an unpopular monarchy with the aim of institutionalizing a republic. General Abd al-Karim Qasim after the coup urgently marginalized his rivals by forming an autocratic government. Irrespective of the fact that General Qasim's revolutionary led government acted as an arbiter of hope on behalf of Iraq's longexploited poor population, yet nothing was done to advance a stable government or strong national institutions in a country that is long split within the boundaries of ethno-sectarian lines. Later on 1963 a group of army officers who identified themselves as members of Ba'ath Party comprising people who oppose Western ideology, and people who are rooted in Arab unity with the influence of socialism carried out a coup overthrowing General Abd al-Karim Qasim led government. Subsequently, the political atmosphere in Iraq was characterized by history of coup until July 17, 1968, when a Ba'ath party chieftain Ahmed Hassan al-Bakr consolidated a one party system in Iraq. Similarly, Ahmed Hassan al-Bakr led government was later sacked by another coup organized by members of his party.

\section{Iraqi politics during/after Saddam Hussein era}

Saddam Hussein has always been a key politician in Iraq's politics and was at the center of Iraq's politics for about a quarter century. He ruled as the country's head of state for over eleven years until 2003 when he was ousted. His rise to power was so remarkable and he made himself an undisputed leader. Karsh and Rautsi (1991), points out that his leadership was characterized by skillful manipulations, tenacious perseverance and merciless elimination of his rivals. Saddam's long term in office is considered to be as a result of his hard work, unprincipled manipulation of allies and his enemies alike, and the genuine support from his colleagues. Saddam Hussein was born on April 28, 1937, in al-Ouja (near the town of Tikrit). He had a fatherless childhood. 
Saddam Hussein waged a ceaseless campaign to improve himself, even though there were a lot of difficulties and challenges along the line. This can be seen during his very first years of schooling, which were achieved with the family's objections. The distance from his home to school was another great barrier for his academic career. His decision to go settle in Baghdad in 1955, landed to being a great icon in Iraq. In 1968, after being imprisoned when the Ba'ath Party lose control of Iraq, The Ba'ath regained its powers and made al-Bakr as new president. Al-Bakr was a relative to saddam, and he entrusted Saddam by awarding him one of the highest post in the party, just to make sure the party was in control for a long time. By July 16, 1979, Saddam Hussein became president of the republic of Iraq after the retirement of president al-Bakr. When Saddam became president, he reshuffled the cabinet and merged several cabinet ministries, created a new post of First Deputy Premier and five other posts of deputy of Premiers, and replaced eight ministers. He filled his family into the cabinet, and this became a huge problem after his era.

According to Henderson (Henderson, 1991: 85), Saddam oldest son, Udai, was responsible for the of Saddam's most trusted bodyguard. Another critical situation that affected Saddam's leadership was the mysterious death of the minister of defense, Adnan Khairallah, in a helicopter crash in 1991. Before this incident, Henderson argues that Khairallah had taken the side of his sister, Sajida, when new erupted that Saddam had beaten her in his furry over Udai. The Khairallah branch was significantly short and Saddam could not rely on them for any state activities. This however brought rivalries among them. This situation became inevitable after Hussein Kamel al-Majid, who was the head of the presidential bodyguard, got married to Saddam's oldest daughter, Raghad. The Ibrahim's didn't approve such actions thus it became their fall from grace. The political situation from this period was not so stable.

Henderson (Henderson, 1991: 86), also points out that continues increased in greediness part the way to the fall of Saddam's administration, especially that of Barzan. Despite the strict laws that prohibits bribery especially from officials; Saddam tolerated a large measure of corruption from his closest collaborators so as to maintain their loyalty. Saddam Hussein led government in Iraq was saddled with autocratic rule and undeniable abuse of power, which he centered on himself, and members of his family. However, irrespective of his abuse of power and hegemonic rule, Saddam was able to tight the grip of ethnic divide in Iraq and concentrated more powers at the center of the government in Bagdad.

\section{Iraqi politics Saddam Hussein era}

The fall of Saddam Hussein led-regime in Iraq was a beginning to a completely new political landscape in Iraq. There have so far been different views on such a new beginning however the most widely perceived view is that it was a beginning of political quagmire in Iraqi politics. Having previously agreed on this research that Iraqi politics is divided within different sectarian rivalry, the fall of Saddam Hussein regime further deepened the distrust and sectarian conflicts among the political players in the country. Kenneth Katzman (Katzman, 2009: 9) in his book titled "Iraq: Post Saddam Governance and Security", identified four major factors that categorized post Saddam Hussein Political history in Iraq and they are as follows: Transition process, political reconciliation, economic reconstruction and American assistance, security challenges and responses.

\section{Transition process}

The transitional process is a period of gradual shift of political sovereignty to the indigenous constructed political elites in Iraq. Katzman (Katzman, 2009: 9) argued that the transition period followed different political stages before its realization and he pointed out this period as Occupational period.

After the capture of Saddam Hussein, the United States of America (USA) led-coalition-force set up a government which they believe will restore a political order in Iraq since set up immediate sovereignty government could favor anti- Saddam Hussein group thereby trampling on democracy. "The Administration initially tasked Lt. Gen. Jay Garner (ret.) to direct reconstruction with a staff of USA government personnel to administer Iraq's ministries; they deployed in April 2003. He headed the Office of Reconstruction and Humanitarian Assistance (ORHA), under the Department of Defense (DOD), created by a January 20, 2003, Executive Order" (Katzman, 2009: 9). It was revealed that the administration largely ignored the initial plan of the state department on the future of Iraq after the fall of Saddam Hussein. Instead, Garner and his collaborators started an arrangement to come up with a representative successor regime by arranging a meeting on April $15^{\text {th }}, 2003$ Nassiriyah consisting about 100 Iraqi citizens from different ethnic nationalities. 
Subsequently, a similar meeting of same nature with even a greater number of about 250 Iraqis was held on April 26 2003 and generally agreed to hold another meeting a month later to announce a coalition interim government. However, on May 2003, Bush, President of the United States announced the dissolution of Garner administration and announced Ambassador L. Paul Bremer as the new administrator leading the Coalition Provisional Authority (CPA) in a bid to hold a stronger political role in Iraq. On assumption of duty, Ambassador Bremer quickly discontinued Garner transitional arrangement and appointed an Iraqi advisory body who was non-sovereign, consisting of 25 members of the Iraqi Governing Council (IGC). Consequently, by September 2003, the IGC appointed up to 25 cabinet members to assume ministerial responsibilities with much similarities as the factional and ethnic balance of the IGC, with a slight majority of the Shiite Muslims. Moreover, irrespective of the fact that there were some Sunni figures within the CPA-led administration, many Sunnis still resented the new power structure as overturning their prior dominance (Katzman, 2009: 9). However, there was a huge resentment among the Iraqi's on this appointment, which led to the Kurds and the Shiites to question the prospects of democracy in Iraq.

There was another period known as the transitional administrative Law. Before announcing occupational government, the American government had earlier on announced that the American occupational contingent can only end if there is a completion of a new Iraqi constitution, and holding of a general election for a new government. This task was set to be completed by 2005 . Nonetheless, Katzman (Katzman, 2009: 10), argues that Sistani agitated for quick Iraqi sovereignty by contributing to the November 2003, US announcement which stated that the sovereign state of Iraq would returned to Iraq by June 30, 2004. National elections were to follow suit prior to this, by the end of 2005. The decision was widely accepted and was included in the new constitution of the state. Katzman goes further to argue that the Transitional Administrative Law (TAL) was drafted by the main organs and equally signed on March 8. 2004. The TAL came up with a roadmap for the political transition, which includes: (1) need for elections by January 31, 2005 (for a 275 seat transitional national assembly); (2) drafting of permanent constitution by 15, 2005. There could possibly be a veto of the constitution from any of the three provinces, by a two-third majority. This could however trigger a redrafting and the revote by October 15, 2006.

\section{Interim Government}

The transitional national constitution could not set up a broad framework for forming the national interim/sovereign government joined with the pressure from opposition led Ayatolla on American government. This made American government to select the National Assembly members through the means of national caucuses, thus forcing them to appoint a United Nations (UN) envoy by name Lakhdar Brahimi, to select an interim government. The interim government started work on the $1^{\text {st }}$ of June, 2004, and the handover ceremony took place on the $28^{\text {th }}$ June, 2004. The ruling faction mainly dominated the interim government with a Sunni leading as the president. President Ghazi al-Yawar and Prime Minister Iyad al-Allawi headed a cabinet of 26 ministers, of which 6 of them were women. The forming of the new interim government leads to an end to occupational regime and resulted in establishing a new American embassy in since January 1991 with Ambassador Christopher Hill as the new ambassador with about 1,100 staffs.

2005 Election

After political sovereignty of Iraq was gained the main focus was on how to establish a credible political structure in Iraq that will promote a long lasting unity government. The objective of the 2005 election was to create a political structure in Iraq; an ambition which was achieved but only lasted until the removal of Prime Minister Nur al-Maliki in 2014 which plus other security challenges is yet to organize a fresh election in Iraq.

- On January $30^{\text {th }} 2005$ election took place on a transitional national Assembly, on a four years' term by 18 provincial councils. According to Katzman, (2009, p. 11), the Sunni Arabs who are still resentful of the US invasion boycotted the elections. No major Sunni Slates were offered, thus enabling the Shiite United Iraqi Alliance (UIA) to win as the majority (140 of the 275 seats). "Sunni slates" were offered, enabling the Shiite United Iraqi Alliance (UIA) to win a slim majority (140 of the 275 seats).

- After the election a constitution-drafted committee was appointed and their findings approved by October 2015. However, the Sunni opponents had a two-third 'no vote' within the two provinces, but not among the three required provinces to veto the constitution. The main 
grievances of the Sunnis were the weakness act of the federal character giving more autonomy to the provinces in the constitution. This autonomy granted regional governments on the right to own their internal security forces, and to have full control of the internal energy resources.

- By December 15, 2005 elections (for a full four-year term government), some Sunnis who were seeking for ways to strengthen their position so as to amend the constitution, fielded electoral slates. UIA alone was not enough to secure enough seats based on the fact that two-third majority was needed to unilaterally form a government. In April 22, 2006, the Sunnis, Sadr faction, secular grouping, and Kurds wanted Jafari to be replaced as Prime Minister and Nuri al-maliki to take over his position as new Prime Minister. Maliki, however, won the approval of a cabinet on May 20, 2006 (Katzman, 2009: 11).

\section{Political reconciliation}

One of the major challenges of Iraq after a successful enthronement of national government was how to achieve a national unity owing to the deep resentment that has so far divided the Iraqi state. Although many political scholars believe that the withdrawal of American troops was an indication of reconciliation and a stable Iraqi national government. However, between the periods of 2008-2012 there was a great deal of legislative and political achievement especially the adoption of De-Ba'athification reform law. A clear stipulation of law was made on the power of provincial councils, amnesty law for detainees, passage of 2008, 2009, 2010, 2011 national budget and peaceful conduction of January 2009 provincial election. The onset of al-Maliki government was a promise of unity government not until 2012 when he started his policy of political polarization built under the axis of corruption. Irrespective of the fact that the Iraqi constitution allowed the regional governments some elements of political autonomy however the decision made at the federal level still influences political actions in Iraq.

The provincial election of January 2009 boosted the political reconciliation of Sunnis and the Shiites and at the same time strains the relations between the Kurdish regional government and the national government. Based on 2008 constitution, the regional governments have the political rights of electing their regional governors and provincial regional administrators in their regions giving them more powerful political control over their state affairs. The election had been slated for October 2008 however due to dispute of integrating the Kirkuk and other territories into the Kurdish control areas thus caused the Talabani veto of the elections that took place in June 2008. Subsequently the major political blocks accepted to put the Kirkuk dispute aside and proceed for the election. The road to achieving a broad range of political reconciliation in Iraq in the current post Saddam era is still a far journey to attain. However, the presence of al-Abadi is still guarantying hope yet the security turmoil is worsening the chances.

\section{Security challenges and responses}

As far back as the fall of Saddam Hussein led-regime, the security challenges in Iraq has so far became increasingly more threatening. No doubt why some scholars attributed the cause of Iraqi security turmoil to the invasion of United States Army and its coalition forces in 2003. However, it cannot be denied that the USA on its own part has so far employed different security techniques to curtail the situation. Nonetheless, it keeps growing in dimension from sectarian conflicts to what is widely perceived as terrorist challenges. Because the content of this research is limited to impact of ethno politics in Iraqi politics, the study will not go in detail in analyzing weather the security challenges in Iraq is born out of terrorism or not. Rather the research will attempt to look inward into the nature, role and influence of ethno-politics in the security challenges in Iraq. The truth of the matter is that no amount of foreign backed intervention can restore security in Iraq. In that case it requires Iraqi citizens themselves to come to terms with the situation and foster a comprehensive and a long lasting security approach that will keep Iraq safe.

Most empirical literatures on ethno political studies reviewed in this research so far suggested that multiethnic societies are more prone to conflict, thus, posing a high risk of security threat, see Moynihan 1993; Ryan 1990; Carment 1993; Joseph Rothschild 1981; Chandra 2001. In the case of Iraq, where such premise seems to be true, however, it is not correct going back to trace the origin of the State of Iraq. The problem of Iraqi security failure started when Sunni Arab led insurgency together with an Al-Qaeda affiliate started growing discontent over the trend of Iraqi leadership, which sees the Shiites, and Kurds grow to power. Some Sunni insurgents aimed at restoring the lost Sunni political dominance and hence shift power back to Ba'ath Party. According 
to record, the Ba'ath Party senior political elites refused political negotiation with the USA on returning power to central government.

Interestingly, Iraqi security challenges is always associated or motivated by political events in the central government of Iraq. Between the periods of 2009 and 2013, security situation in Iraq was relatively calm owing to the fact of the existing government in Bagdad. But between 2013 till date, Iraq security conditions have seen its eclipse owing to the rise of the so-called Islamic State of Iraq, and the Syria-ISIS. The state of Iraq today has become a battleground where the West and its allies come to test their weapon of warfare in the name of combating terrorist groups. The security problems in Iraq are born out of political polarization rooted in ethnic resentment and corruption by few political elites who are desperate of political positions.

\section{Conclusion}

Decolonization movement reviewed that the concept of nation-state was not "inscribed into the nature of things" and that ethno-politics plays a significant role in shaping international politics. Ethno-political studies gained momentum in International Relations during the post decolonization movements between the 1960's and 1970's. A lot of ethnic groups with huge political roots are seen in Iraq dated from its historical periods. Many scholars point out that Iraq was created by the British during the former Ottoman Provinces of Mosul, Basra and Baghdad. The British went further to divide the three Ottoman provinces into fourteen. This was so for administrative purposes, and four additional provinces were created. However, Iraq is shaped by a good number of ethnic, cultural and religious forces. Due to inaccuracies in census data coupled with official manipulations, it is difficult to provide a precise statistical breakdown of the population.

Federalism remains a viable political alternative in promoting socio-political cohesion in Iraq. For federalism to function properly in Iraq, certain conditions must be met, and these conditions are discussed as follows: First, cooperation; both the Arabs and the Kurds must agree to cooperate with each other especially on some vital and sensitive issues of political interest. Without a close cooperation among all the Iraqi's, adequate functioning of federalism is unrealizable. Secondly, consensus; there must be a high level of consensus among the Kurds and the Arabs for federalism to work in Iraq. The existence and survival of the state of Iraq should be seen and conceived as paramount by all Iraqi citizens, instead of seeking for individual or ethnic oriented interest. The political elites should be composed of people with the interest of the state at heart and not separationist leaders. Third, compromise; both the Arabs and the Kurds most learn to compromise on certain issues of common and national interest. Since without compromise, most of the outstanding issues between the Arabs and the Kurds cannot be resolved. Fourth, concession; a high degree of concession must be played in Iraqi politics. Since without concession, the interest of the Kurds and Arabs is difficult to be accommodated within the federal level. Significantly, there should an amendment in the constitutional framework on power devolution.

\section{References}

Al-Rubaie, 2008 - Al-Rubaie, M. (2008). Federalism, Not Partition. The Washington Post [Electronic resource]. URL: http://www.washingtonpost.com/wpdyn/content/article/2008 /01/17/ AR2008011702240.html

Anderson, 2006 - Anderson, B. (2006). Imagined Communities: Reflections on the Origin and Spread of Nationalism. Verso, London, New York.

Anderson, Stansfield, 2004 - Anderson, L.D., Stansfield, G.R. (2004). The Future of Iraq: Dictatorship, Democracy, or Division? Palgrave Macmillan, New York.

Auclair, 2005 - Auclair, C. (2005). Federalism: its principles, flexibility and limitations. Forum of Federations, 5 (A-1): 3-5.

Backer, 2009 - Backer, Larry C. (2009).From Constitution to Constitutionalism: A Global Framework for Legitimate Public Power Systems. Penn State Law Review, Vol. 113, No. 3, pp. 671-732.

Barth, 1969 - Barth, F. (1969). Ethnic Groups and Boundaries. Allen and Unwin, London.

Bremer, McConnell, 2006 - Bremer, P., McConnell, M. (2006). My Year in Iraq: the Struggle to Build a Future of Hope. Simon and Schuster, New York.

Burgess, 2006 - Burgess, M. (2006). Comparative Federalism: Theory and Practice. Routledge, London. 
Burgess, Gagnon, 1993 - Burgess, M., Gagnon, A. (1993). Comparative Federalism and Federation: Competing Traditions and Future Directions. University of Toronto Press, Toronto.

Carment, 1993 - Carment, D. (1993).The International Dimensions of Ethnic Conflict: Concepts, Indicators, and Theory. Journal of Peace Research, 30 (2): 137-150.

Erk, 2008 - Erk, J. (2008). Explaining Federalism: State, Society and Congruence in Austria, Belgium, Canada, Germany and Switzerland. Routledge, Abingdon.

Fitzsimmons, 2008 - Fitzsimmons, M. (2008). Centralization or Decentralization in Iraq? In Search of the Elusive Sweet Spot. Alexandria, VA: Institute for Defense Analyses [Electronic resource]. URL: https://www.ida.org/ /media/Corporate/Files/Publications/IDA_Documents/SFRD/2014/_ D3702.ashx

Galbraith, 2006 - Galbraith, P. (2006). The End of Iraq: how American Incompetence Created a War Without End. Simon and Schuster, New York.

Hale, 2008 - Hale, H.E. (2008). The Foundations of Ethnic Politics: Separatism of States and Nations in Eurasia and the World. Cambridge University Press, Cambridge.

Henderson, 1914 - Henderson, S. (1991). Instant Empire: Saddam Hussein's Ambition for Iraq.Mercury House, San Francisco.

Karsh, Rautsi, 1991 - Karsh, E., Rautsi, I. (1991). Saddam Hussein: A Political Biography. The Free Press, New York.

Katzman, 2009 - Katzman, K. (2009). Iraq: Post-Saddam Governance and Security [Electronic resource]. URL: https://fas.org/sgp/crs/mideast/RL31339.pdf

Kirmanj, 2013 - Kirmanj, S. (2013). Identity and Nation in Iraq [Electronic resource]. URL: https://www.rienner.com/uploads/511e6527daedf.pdf

Lalande, 1978 - Lalande, G. (1978). In Defence of Federalism: A View from Quebec. McClelland and Stewart Limited, Toronto.

Lobell, Mauceri, 2004 - Lobell, S. E., Mauceri, P. (2004). Ethnic Conflict and International Politics: Explaining Diffusion and Escalation. Palgrave Macmillan, Houndmills, Basingstoke, Hampshire.

Lockhart, 2014 - Lockhart, P.G. (2014).Geopolitics, Borders, and Federalism: Challenges for Post-War Iraq [Electronic resource]. URL: https://digitalcommons.wku.edu/cgi/viewcontent.cgi? referer=https://www.google.com.tr/\&httpsredir $=1 \&$ article $=2446 \&$ context $=$ theses

Marr, 2012 - Marr, P. (2012). The Modern History of Iraq. Westview Press, Boulder, CO.

Merritt, 2007 - Merritt, D. (2007). Is Federalism Based on Ethnic Partition a Viable Solution in Iraq? (Master's thesis), Army Command and General Staff College, Fort Leavenworth, KS. Press.

Mill, 2009 - Mill, J.S. (2009). Considerations on Representative Government. The Floating

Moravcsik, 2003 - Moravcsik, A. (2003). Liberal International Relations Theory: A Scientific Assessment. Progress in International Relations Theory: Appraising the Field, edited by C. Elman and M.F. Elman, Cambridge, MIT Press.

O'Leary, 2010 - O'Leary, B. (2010). Thinking about Asymmetry and Symmetry in the Remaking of Iraq. In M. Weller and K. Nobbs (eds.) Asymmetric Autonomy and the Settlement of Ethnic Conflicts. Philadelphia, PA: University of Pennsylvania Press, pp. 183-209.

Saikal, 2003 - Saikal, A. (2003). Democratization in the Middle East: Experiences, Struggles, Challenges. Institute of Samoan Studies, Tokyo, Japan.

Schweller, 2004 - Schweller, R. L. (2004). Unanswered Threats: A Neoclassical Realist Theory of Underbalancing. International Security, 29 (2):159-201.

Shakir, 2014 - Shakir, F. (2014). The Iraqi Federation: Origin, Operation and Significance [Electronic resource]. URL: https://kar.kent.ac.uk/47838/1/The\%20Iraqi\%2oFederation.pdf

Stein, 1971 - Stein, M. (1971). Federal Political Systems and Federal Societies. Canadian Federalism: Myth or Reality, Meekison,J. (Ed.), Methuen, Toronto.

Sullivan, 2013 - Sullivan, M. (2013). Middle East Security Report 10: Maliki's Authoritarian Regime. Washington, D.C.: Institute for the Study of War. [Electronic resource]. URL: http://www.understandingwar.org/sites/default/files/Malikis-Authoritarian-RegimeWeb.pdf

Türkmen, 2012 - Türkmen, H.S. (2012). Ethnic Politics in International Relations: The case of Volga Tatars [Electronic resource]. URL: http://www.thesis.bilkent.edu.tr/oo05032.pdf 